\title{
GIS-based landscape analysis of megalithic graves in the Island of Sardinia (Italy)
}

\author{
Riccardo Cicilloni ${ }^{1}$, Marco Cabras ${ }^{2}$ \\ 1. Department of History, Cultural Heritage and Territory, University of Cagliari. Via Is Mirrionis 1, \\ 09123 Cagliari, Italy. Email: r.cicilloni@unica.it \\ 2. Universidad de Granada. Via Is Mirrionis 119, 09121 Cagliari, Italy. Email: marcocabras@correo.ugr.es
}

\begin{abstract}
:
One of the most important megalithic groups in Western Europe in terms of number and characteristics is the group of over 200 monuments of various types in Sardinia. It now seems to be confirmed that the rise of the megalithic phenomenon was during the culture of San Michele of Ozieri (Late Neolithic, 4000-3300 B.C.E.). The Sardinian dolmen graves, however, had a maximum distribution during the Chalcolithic, as evidenced by most of the finds from excavations. The phenomenon also shows a close relationship beyond Sardinia and especially with the monuments of Catalonia, Pyrenees, non-coastal departments of French-midi, Corsica and Puglia.

About 90 dolmen graves of various types have been investigated, namely the simple type, "corridor" type, "allée couverte" type, and others of uncertain attribution, located in central-western Sardinia, and particularly in a significant area of ca. $3500 \mathrm{~km}^{2}$ coinciding with the historical regions of Marghine-Planargia, Middle Valley of Tirso and Montiferru. This includes some $40 \%$ of all Sardinian dolmens. Locational trends and relationships with regard to landscape elements were studied with the aid of GIS methodologies such as viewshed and cost surface analysis. This allowed an evaluation of the role of visual dominance on the surroundings in relation to waterways and natural access routes.

These dolmens enjoy an isolated positional character, being found more often in high plateaus, but also on low plateaus and hills. Although different concentrations are found in dolmenic graves, these do not seem to have any direct relationship among them, but their influence is apparently directed towards travel routes and sensitive elements of the landscape that have capabilities of territorial demarcation.

The particular location emphasizes the significance of these monuments as territorial markers for segmentary societies. It seems that a dolmen was constructed according to the territory immediately surrounding it. This reinforces the hypothesis of there being a secondary task, in addition to that of burial, to symbolize a message or landmark for those who moved towards "another" territory: a sign of belonging.
\end{abstract}

Keywords: dolmen; GIS; landscape; Neolithic; Sardinia

\section{Sommario:}

Uno dei più importanti gruppi megalitici dell'Europa occidentale in termini di numero e caratteristiche è quello presente in Sardegna, che consta di oltre 200 dolmens. Sembra essere

Published by the School of History, Classics and Archaeology, University of Edinburgh ISSN: 2055-0472. URL: http://journals.ed.ac.uk/lithicstudies/

This work is licensed under a Creative Commons Attribution 2.5 UK: Scotland License. 
confermato che la genesi del fenomeno sia avvenuta durante la cultura di San Michele di Ozieri (Tardo Neolitico: 4000-3300 B.C.E.). I dolmen sardi, però, hanno avuto la loro massima diffusione durante il Calcolitico, come evidenziato dalla maggior parte dei reperti provenienti dagli scavi. Il fenomeno dolmenico sardo mostra anche strette relazioni con aree extra-insulari, soprattutto con i dolmens della Catalogna, dei Pirenei, con quelli delle province non-costiere del sud della Francia continentale, con la Corsica e la Puglia, nell'Italia meridionale.

Sono stati analizzati in questa sede circa 90 dolmens di varie tipologie: di tipo semplice, a "corridoio", ad 'allée couverte' e altri di attribuzione incerta, situati nella Sardegna centro-occidentale, e in particolare in una zona significativa di circa $3500 \mathrm{~km}^{2}$, coincidente con le regioni storiche del Marghine-Planargia, della Media Valle del Tirso e del Montiferru. Il campione indagato comprende così il $40 \%$ circa di tutti i dolmens sardi. Sono state studiate le tendenze ubicazionali e le relazioni con gli elementi del paesaggio con l'ausilio di metodologie GIS come la viewshed analysis e la least-cost path analysis.

I dolmens analizzati si trovano più spesso presso altipiani, ma anche su colline basse. Sono prevalentemente isolati, ma in rari casi sono raggruppati in necropoli. Sebbene in alcune aree siano stati individuati dei raggruppamenti di questi monumenti, essi non sembrano però avere rapporto diretto tra loro, ma la loro ubicazione è probabilmente legata a vie di percorrenza e ad elementi sensibili del paesaggio, così da suggerire un ruolo di marker territoriale.

La particolare posizione sottolinea il ruolo di questi monumenti come marcatori territoriali per società segmentarie. Sembra che i dolmens siano stati edificati in relazione col territorio immediatamente circostante. Questo dato rafforza l'ipotesi che i dolmens, oltre che la funzione primaria di sepoltura, svolgessero anche un compito secondario, con l'obbiettivo di simboleggiare un messaggio o rappresentare un punto di riferimento per coloro che avevano la necessità di muoversi verso territori pertinenti a diversi gruppi umani: un segno di appartenenza.

Parole chiave: dolmen; sistema informativo territoriale; archeologia del paesaggio; Neolitico; Sardegna

\section{Introduction}

In Sardinia archaeologists have shown an important megalithic phenomenon, consisting of over 200 dolmens, situated for the most part in the central-northern area of the island. Currently, we know of at least 221 dolmen monuments. As regards typology, the dolmens belong to five main categories: simple type, "corridor" type, "side entrance" type, "mixed" type (i.e. monuments partly excavated in the rock and partly built with orthostats and dolmenic coverage) and 'allées couvertes'. The majority of the dolmenic burials belong to the simple class, followed by the allees couvertes, while only few tombs are of other kinds.

From the point of view of chronology, there are no radiocarbon dates. The data from recent stratigraphical investigations, the archaeological materials sporadically recovered in some dolmens, the structural and cultural relationships among the Sardinian dolmens and other prehistoric monuments of the island, typological comparisons with similar dolmenic monuments of various extra-insular areas, allow however to report that the dolmens of Sardinia belong to a time period ranging from the late Neolithic to the Eneolithic (from the end of the fourth to the beginning of the second millennium B.C.E.), perhaps with a degree of reuse in the Bronze age.

Recent research has highlighted tight structural and cultural relationships between the megalithic monuments of Sardinia with some extra-insular regions, as in Iberia, France and especially Corsica.

In the present work we want to analyze systematically the relationship among the megalithic graves and the surrounding environment. We believe that the lithology and especially the geomorphology are extremely important factors in order to better understand the dolmen phenomenon and the locational modalities of these burial structures. 
To achieve the proposed objective, it was decided to study the dolmens present in a sample area of west-central Sardinia, characterized by a high concentration and, regarding the geomorphological aspect, especially by a plateau environment, that constitutes the preferred morphological landscape for the building of dolmens across the whole island (Figure 1).

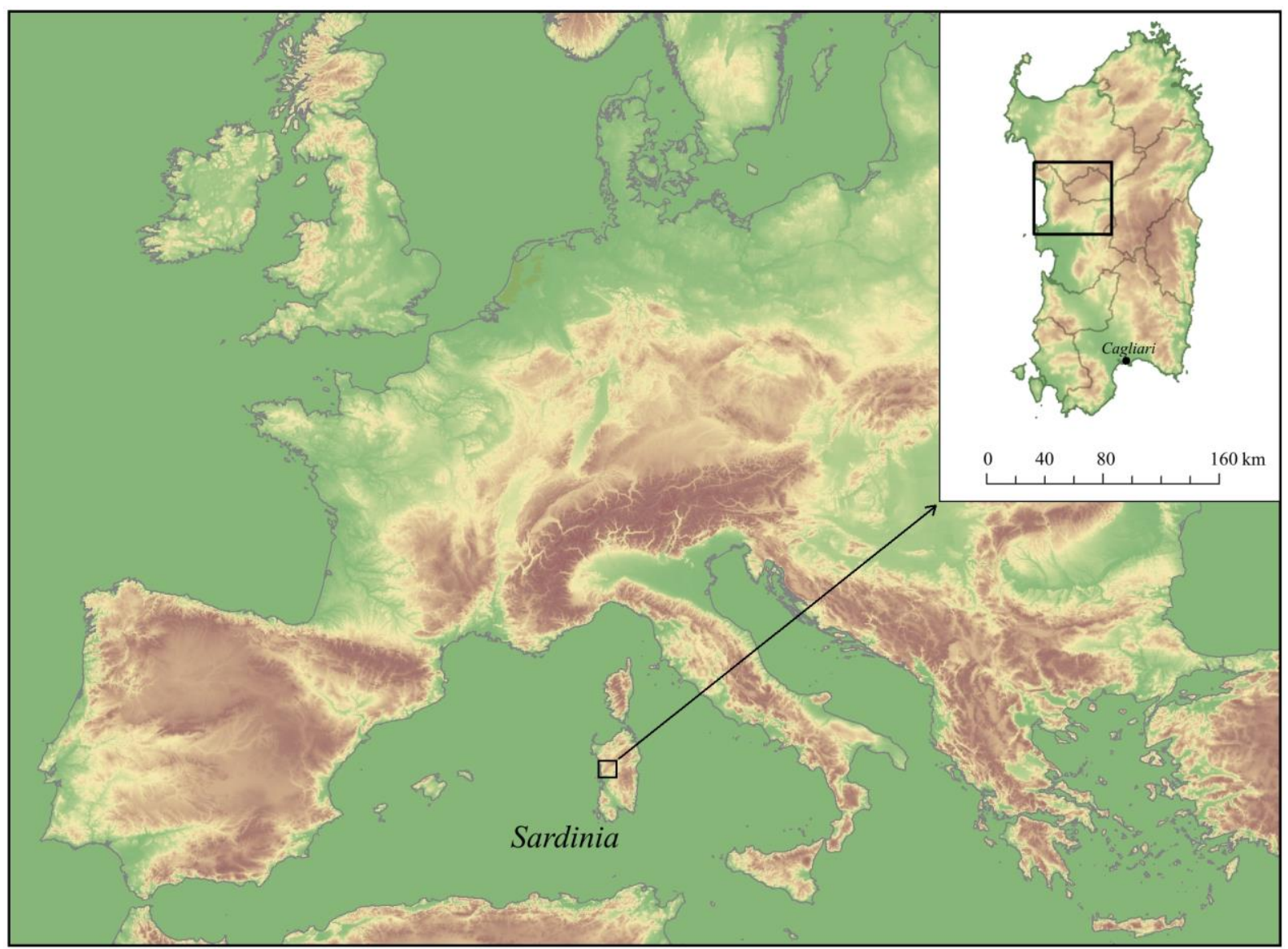

Figure 1. Sardinia and the study area (Elaboration of the Authors on the basis of a raster map of the European Environment Agency).

\subsection{The territory}

The geographical zone under consideration includes an area of about $1790 \mathrm{~km}^{2}$; it consists of three areas characterized by geomorphological forms typical of the plateau, known as the highlands of Abbasanta, Campeda and Planargia (Figure 2), and two mountain ranges, Montiferru and Marghine, that form an arc from southwest to northeast. The largest area is the basaltic plateau of Abbasanta, whose surface is slightly inclined from north-west to southeast: it is not very rugged, the valleys are few and hardly visible, and average altitude varies from 300 to $400 \mathrm{~m}$. a.s.l. (Mori 1975).

The formation of the plateau took place during the Middle-Upper Pliocene, when in Sardinia the tectonic graben of the Campidano began to descend and volcanic activity awoke, particularly in the Monte Arci and in Montiferru: the copious basaltic emissions gave rise to the vast basaltic plateaus characteristic of the central and northern parts of the island. It was the same origin for the Campeda plateau which extends to the north of Abbasanta plateau. It is separated from the Marghine near the mountain formations included in today's territories of Lei, Silanus, Bolotana, Bortigali and Macomer. At the western border of Campeda there is the Planargia region which, as the name suggests, indicates a small zone mainly flat and set on two levels: the upper one (average altitude $340 \mathrm{~m}$ ) is a basaltic plateau, the lower one with 
hillside peculiarity slopes down to the mouth of the river Temo and the region of Villanova, which marks the north-west border.

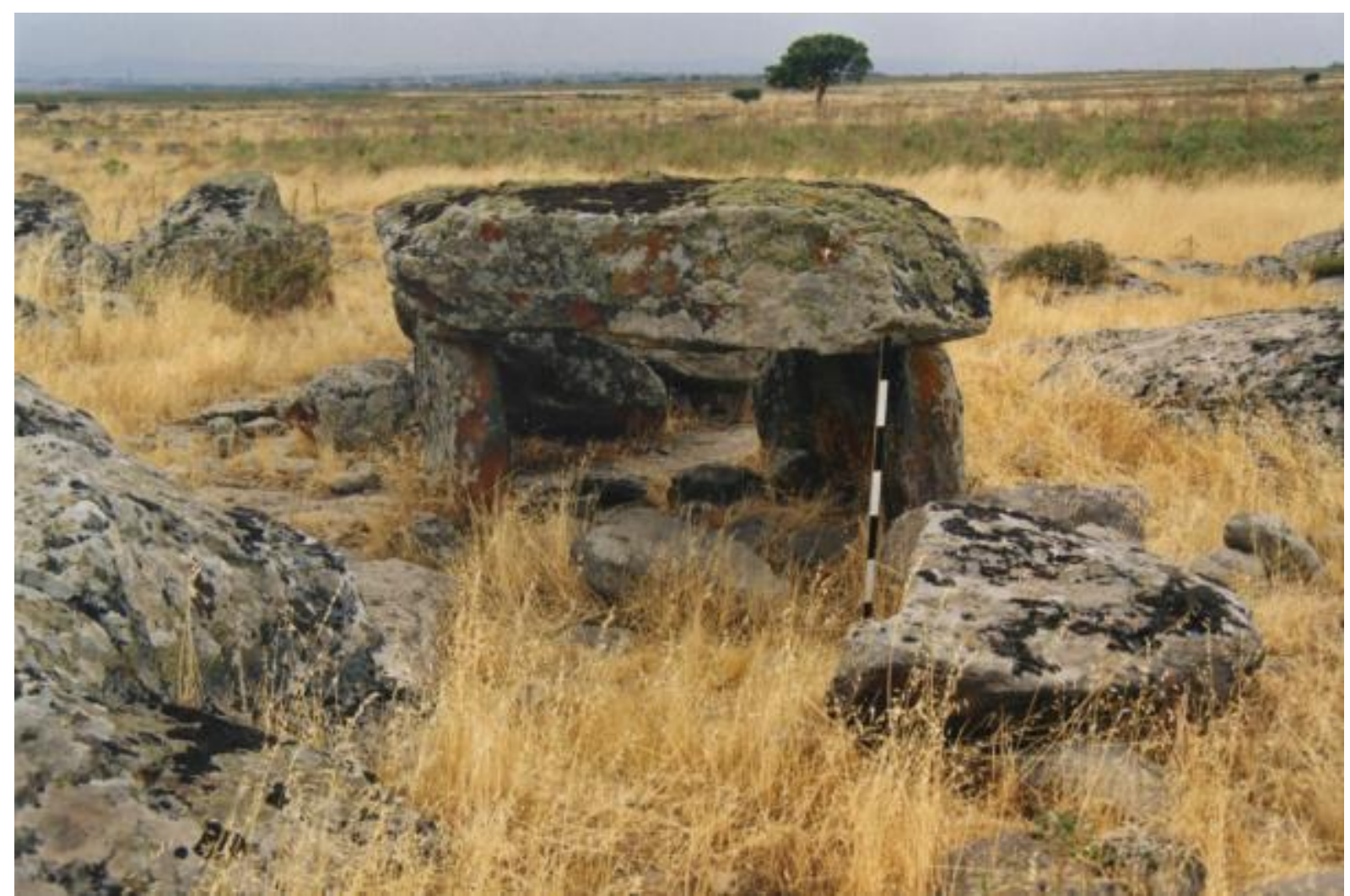

Figure 2. Dolmen Terra Tenera-Macomer. In the background is the plateau of Campeda (photo by R. Cicilloni).

The Planargia is limited to the west by the sea and to the south by the Riu Mannu that separates it from the Montiferru. In the north-east the area is bordered by the Marghine. Finally mountainous areas delineate the areas of plateau. The Montiferru is the largest of the ancient Sardinian volcanic systems, consisting of a set of trachytic and basaltic rocks that extend for about $700 \mathrm{~km}^{2}$, reaching the highest elevation with Monte Urtigu (1050 m a.s.1.).

The whole is a complex that appears like a big flattened cone with simple and regular shapes but strongly affected by valleys that descend from all sides except the north-east, where the mountain connects with Marghine and Campeda. The central backbone of the massif is composed of trachytic lavas, while the sides of higher slope comprise basaltic flows younger than the central lavas. The basalts that expanded on the sides of this ancient volcano constitute today a large crown of plateaus that characterizes the environment of our study. As just mentioned, in the north-east of Montiferru there is the Marghine massif characterized to the south by steep slopes and much more rugged shapes. In another way we can say that the two environments are closely related: in fact the Marghine constitutes the hem of Campeda, which further east, towards the Tirso valley, occurs with steep forms and imposing fronts at the territory of Bortigali. Among the highest peaks of Marghine are Monte Santu Padre $(1030 \mathrm{~m})$, Punta Iammeddari $(1118 \mathrm{~m})$, and the highest peak Punta Palai (1200 $\mathrm{m}$ above sea level). The Campeda plateau instead has an average altitude of 650 meters.

\subsection{Previous research}

The presence of megalithic graves in Sardinia was known since the beginning of last century. The first scientific work that concerns a Sardinian dolmen was, the article published by the archaeologist Taramelli (1906), who reported the existence of the dolmen Sa Perda 'e 
S'Altare in the territory of Macomer, the first monument of this type discovered in Sardinia. Subsequently, Taramelli $(1916 ; 1919)$ and other scholars took up the argument, among them Mackenzie (1910; 1913), Davies (1939), Lilliu (1968; 1988), Atzeni (1968; 1982; 1988), Santoni (1973), and Moravetti (1998a). Finally, there is a book by Cicilloni (2009) about all known Sardinian dolmens.

However, none of the cited studies treated specifically the relationship between dolmens and the landscape. They merely note that the morphological environment in which these burial buildings most often rise is the plateau, followed by low tablelands and hilly areas (Cicilloni 2009: 136), with all environments linked in the past and the present to a pastoral economy (Lilliu 1988: 197).

As regards the area under examination, besides information provided by the researchers mentioned above, there are only signalings of single dolmenic monuments: for example, in the works on the historic regions of Marghine and Planargia (Moravetti 1998b; 2000) and on the areas of Cuglieri (Pes 2009), Sedilo and Aidomaggiore (Tanda 1996; 1997; 1998), Abbasanta and Norbello (Cicilloni 1997; Usai 1999), Narbolia (Usai 2005), Neoneli (Loi 2012), and Bonarcado-Seneghe (Maisola 2012).

However, there are no studies and reflections on the dolmen megalithism of the area in general, except for the observation of some authors on specific zones of the sample area: for example the analysis of Moravetti (2000: 36-38) on Marghine-Planargia and the accurate exposure of Paschina (2000: 428-434) on the dolmen phenomenon in the territory of Macomer.

In Sardinia no GIS-based territorial analysis has ever been done regarding the dolmens. The GIS methodology for the study of the archaeological landscape has been applied till now only on sites and monuments of protohistoric age (see for example, Puggioni 2009; Angius et al. 2010, 2012; de Montis \& Caschili 2012; Fenu et al. 2012; Sanna 2012; Vanzetti et al. 2013; Cicilloni \& Cabras 2014).

\subsection{Dolmen graves in the sample area}

In the examined area there are 90 megalithic tombs. The largest concentration $(71 \%$ of total) is localized at the plateaus of Abbasanta (64\%) and Campeda in the North of Macomer (7\%). (Figure 3).

This area of concentration, located in the South of the Marghine, sees the presence of the vast majority of the monuments subjected to this analysis. The other areas of concentration of dolmens, again in a plateau environment, are those of Suni and Sindia (12\%), lowland areas in the countryside of Cuglieri sloping down to the high sea coasts between Torre Foghe (mouth of the Riu Mannu) to the north and Santa Caterina di Pittinurri (mouth of Riu Santa Caterina) to the south, and the foothills of Montiferru near Narbolia (3\%). Their locations in rugged areas have lower rates (14\% of the monuments). $83 \%$ then are located in plateau, some crowning the edges and corners with a large view of the land below or the canyons that penetrate these volcanic formations. Others, such as the dolmen Baccarzos of Noragugume, are located at lower altitudes, at entrances to canyons that from lower territories rise to the top of the highlands. However, most of the analyzed dolmens are located at the centre of the highlands, away from these positions listed above with a scattered distribution across the territory which tends to his massive occupation. 


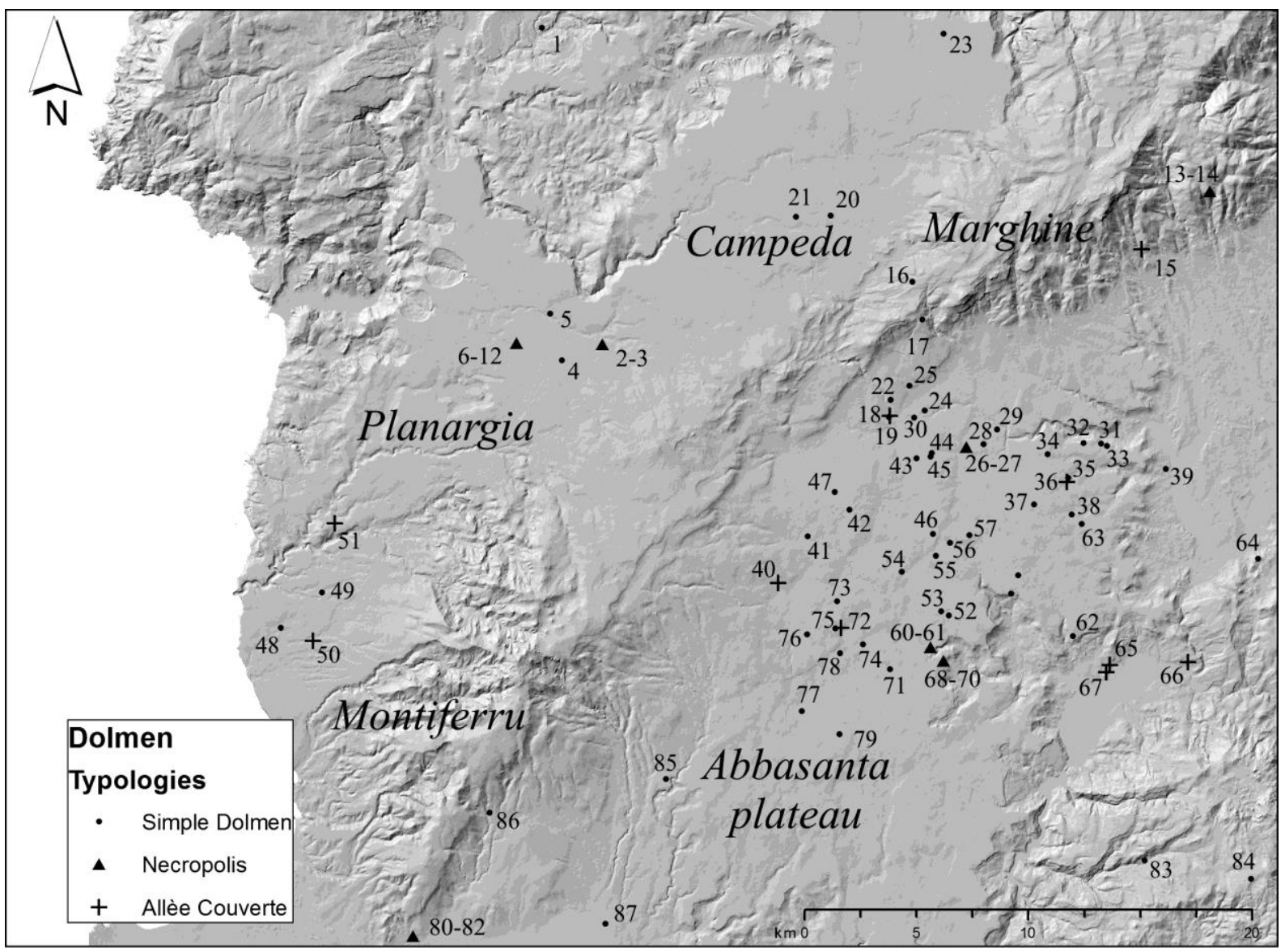

Figure 3. Map of distribution of the examined dolmens: 1. San Sebastiano-Padria; 2. Nela I-Sindia; 3. Nela IISindia; 4. Serrese-Sindia; 5. Furrighesu-Sindia; 6. Matta Larentu I-Suni; 7. Matta Larentu II-Suni; 8. Matta Larentu III-Suni; 9. Matta Larentu IV-Suni; 10. Matta Larentu V-Suni; 11. Matta Larentu VI-Suni; 12. Matta Larentu VII-Suni; 13. Tanca Noa A-Bolotana; 14. Tanca Noa B-Bolotana; 15. S. Basilio-Lei; 16. TuideBortigali; 17. Carrarzu Iddia-Bortigali; 18. Sa Perda 'e S'Altare-Macomer; 19. Tanca Sa Marchesa-Macomer; 20. Su Edrosu-Macomer; 21. Terra Tenera-Macomer; 22. Bidui-Macomer; 23. Aeddo-Macomer; 24. Sa Tanca Sar Bogadas-Birori; 25. Noazza-Birori; 26. Arbu I-Birori; 27. Arbu II-Birori; 28. Corrizzola-Birori; 29. Mura Pranosa-Birori; 30. Pradu Lassia-Birori; 31. Sa Fronte Uda-Dualchi; 32. Mazzarighe A-Dualchi; 33. Mazzarighe B-Dualchi; 34. Lughe-Dualchi; 35. Badde Ide-Dualchi; 36. Brancatzu-Dualchi; 37. Paule Rues-Dualchi; 38. Baratta-Dualchi; 39. Baccarzos-Noragugume; 40. Pedra in Cuccuru-Borore; 41. Giuanne Pedraghe-Borore; 42. Muttianu-Borore; 43. Sa Matta e sa Ide-Borore; 44. Serbine A-Borore; 45. Serbine B-Borore; 46. ArghentuBorore; 47. Su Narbanu-Borore; 48. Monte Lacana-Cuglieri; 49. Su Livrandu-Cuglieri; 50. Su Lizu-Cuglieri; 51. Sa Cobelcada-Sennariolo; 52. Succhiau-Aidomaggiore; 53. Mura Fratta-Aidomaggiore; 54. TuvameneAidomaggiore; 55. Nucrastala-Aidomaggiore; 56. Meddaris-Aidomaggiore; 57. Su Nuradorzu-Aidomaggiore; 58. Scarallotza-Aidomaggiore; 59. Crobecada-Aidomaggiore; 60. S'Aspru I-Aidomaggiore; 61. S'Aspru IIAidomaggiore; 62. Iloi-Sedilo; 63. Lure-Sedilo; 64. Filigorri-Sedilo; 65. Monte Trigu-Sedilo; 66. TorozzulaSedilo; 67. Monte Paza-Sedilo; 68. Nurarchei A-Norbello; 69. Nurarchei B-Norbello; 70. Nurarchei C-Norbello; 71. Abbamuru-Norbello; 72. Sa Perda Piccada-Norbello; 73. Sa Codina 'e S'Ispreddosu-Norbello; 74. Mura 'e Iscovas-Norbello; 75. S'Angrone-Abbasanta; 76. Mesu Enas-Abbasanta; 77. Cannigheddu 'e S'Ena-Abbasanta; 78. Mura 'e Putzu-Abbasanta; 79. Su Nuratzolu-Abbasanta; 80. Carrazzu I-Narbolia; 81. Carrazzu II-Narbolia; 82. Carrazzu III-Narbolia; 83. S. Maria di Olisai-Neoneli; 84. Nole-Neoneli; 85. Serra Crastula-Bonarcado; 86. Serra Passa-Seneghe; 87. Su Conzau de Is Froris Grogus-Milis (Elaboration of the Authors).

We note that these dolmens are rarely grouped in necropoli (except for Matta LarentuSuni, with at least seven, Nurarchei-Norbello and Carrazzu-Narbolia, with three dolmens), but are usually located in isolated places or, when there are several in the same area, at a good distance from each other, almost as if delimiting in some way a piece of territory. 
The megalithic tombs of this area are mostly simple dolmens (71\%) (Figure 4), but also allées couvertes (15\%) (Figure 5). Among the simple dolmens, their plans are mainly quadrangular $(68 \%)$, but also circular $(32 \%)$. So are of uncertain typological attribution.

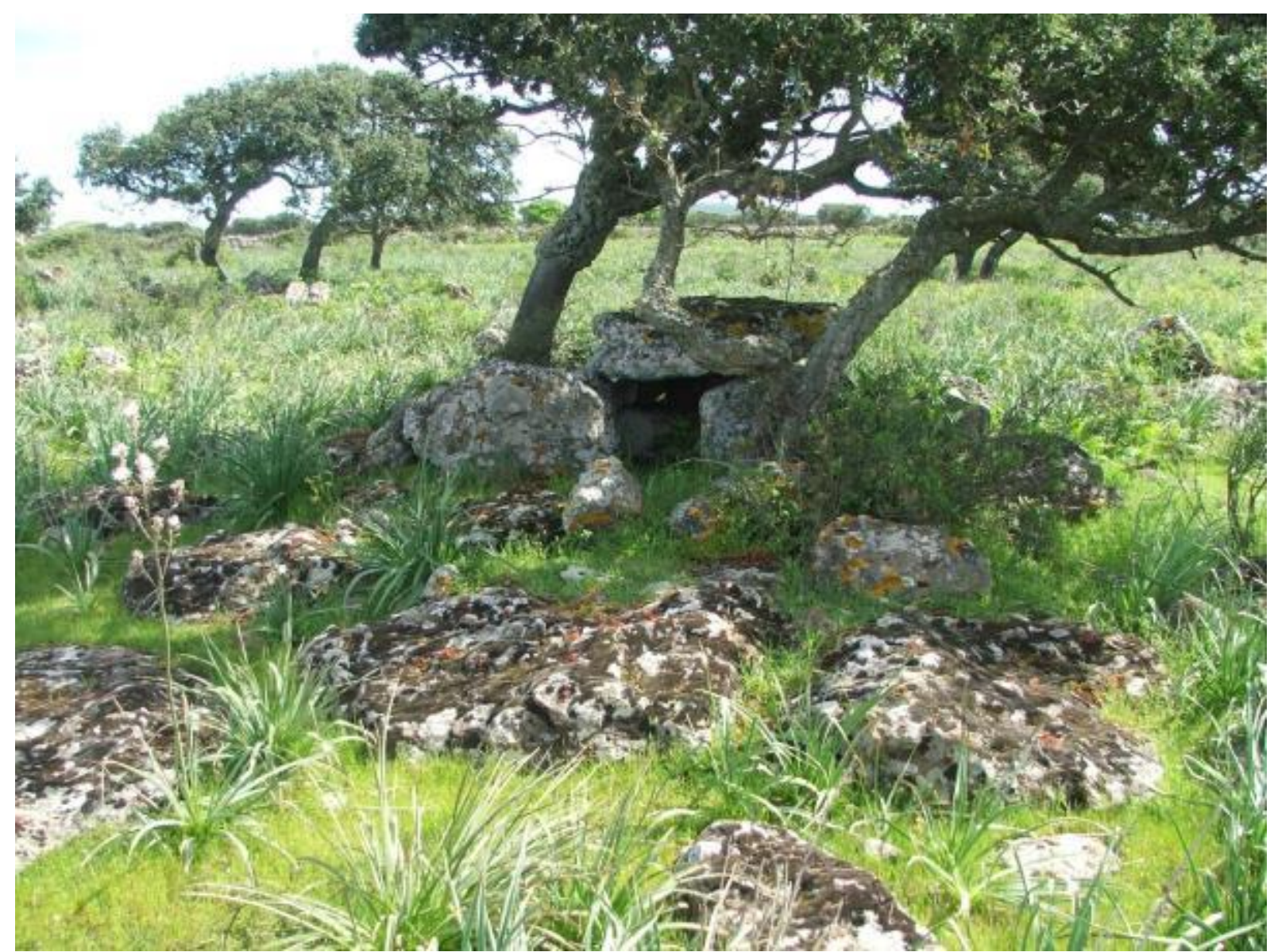

Figure 4. Dolmen Matta Larentu I, Suni (simple type) (photo by R. Cicilloni).

The building material most often used is basalt (73\%), being locally the more diffused type of rock having regard to the geological structure of the area. Also used was trachyte, granite and limestone.

The orientation of the entrances of the dolmens is interesting (Hoskin 2001). In Sardinia we know the orientation of only 52 dolmens (60\% of the total). We cannot determine the orientation of the others because they are destroyed or undetectable. There are orientations toward all the points of the compass, but $52 \%$ of those considered are oriented towards southeast, $13 \%$ to east, $11 \%$ to south-west and $8 \%$ to south, while other directions have lower percentages. These data can be compared with those of the other dolmen tombs of Sardinia, where most of them are orientated to south-east (41\%) (Cicilloni 2009: 151-153). However, this preference is often found in the dolmen monuments of Western Europe: i.e. orientation towards the arc that goes from east to south in dolmens of the Atlantic coasts, from Brittany to the Basque country (Chevalier 1984), in Catalonia (Esteva Cruañas 1970), in some departments of central-southern France (Chevalier 1984) and in Corsica (Cesari 2001). We cannot determine with certainty the reasons for the orientation of the dolmens, but we believe that it is probably connected to magical-sacral motives, so the builders of these monuments chose an orientation related to certain points of the horizon, for example, where the sun rises or sets at certain times of the year (Cicilloni 2009: 152). 


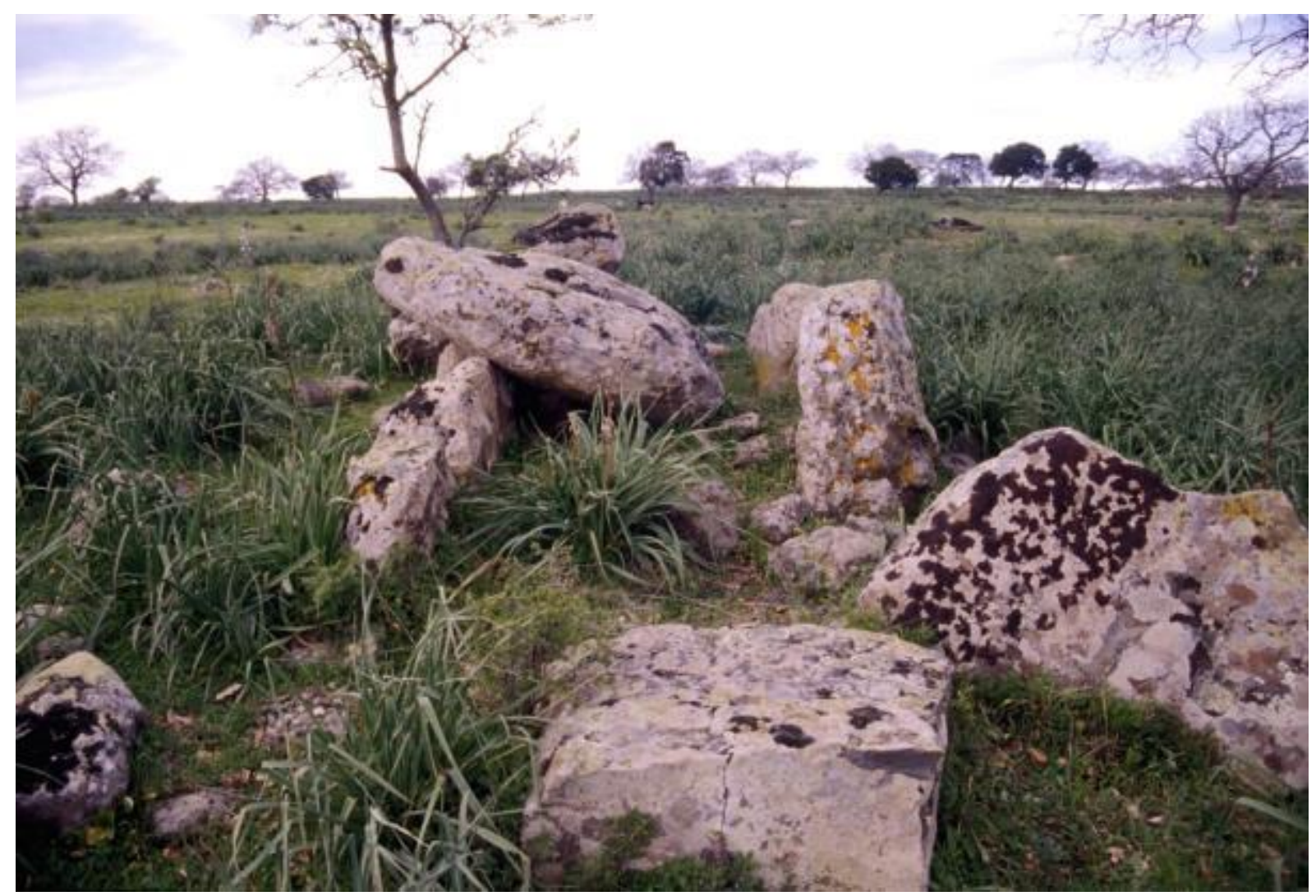

Figure 5. Allée couverte Pedra in Cuccuru, Borore (photo by R. Cicilloni).

The dolmens of Serrese-Sindia and Monte-Paza Sedilo, which are decorated on the upper surface of the coverage slab, stand out in importance.

In the first monument, on the upper surface and on the edges of the slab there are narrow incisions which form, on each of the sides, except the entrance, some figures. Two of them, on the north and west sides, might be anthropomorphic. The figure on the south side is a rectangle, divided into four parts, connected to the figure of the west side. On the south-west and north-east corners there are engraved irregular semicircles. The engravings extend also across the thickness of the slab, and they are cut by a further line which, along the thickness, runs horizontally all around the table (Figure 6).

There are no precise comparisons with other examples of megalithic art in Western Europe, but only very general similarities with "U" motifs and crossed lines engraved on orthostats of French and English dolmens (Shee Twohig 1981).

Engravings are also present on a trachytic slab found in Monte-Paza Sedilo, presumably pertinent to a passage tomb. There is a schematic decoration with shells, concentric circles with a single radial line, and a schematic anthropomorphic female figure (Melis 1996) (Figure 7).

The motifs of concentric circles with a single radial line have close comparisons with the engravings present on some standing stones of the territory of Mamoiada, and in particular on the monumental Stele of Boeli (Fadda 1997; Atzeni 1998; Manca \& Zirottu 1999). Outside of Sardinia, these figurative motifs are found in megalithic monuments of the Irish, for example in the megalithic necropolis of Loughcrew (Co. Meath) (Shee Twohig 1981: 202-220) and on the monumental standing stone of Ardmore (Co. Donegal) (McNally 2006: 98). 


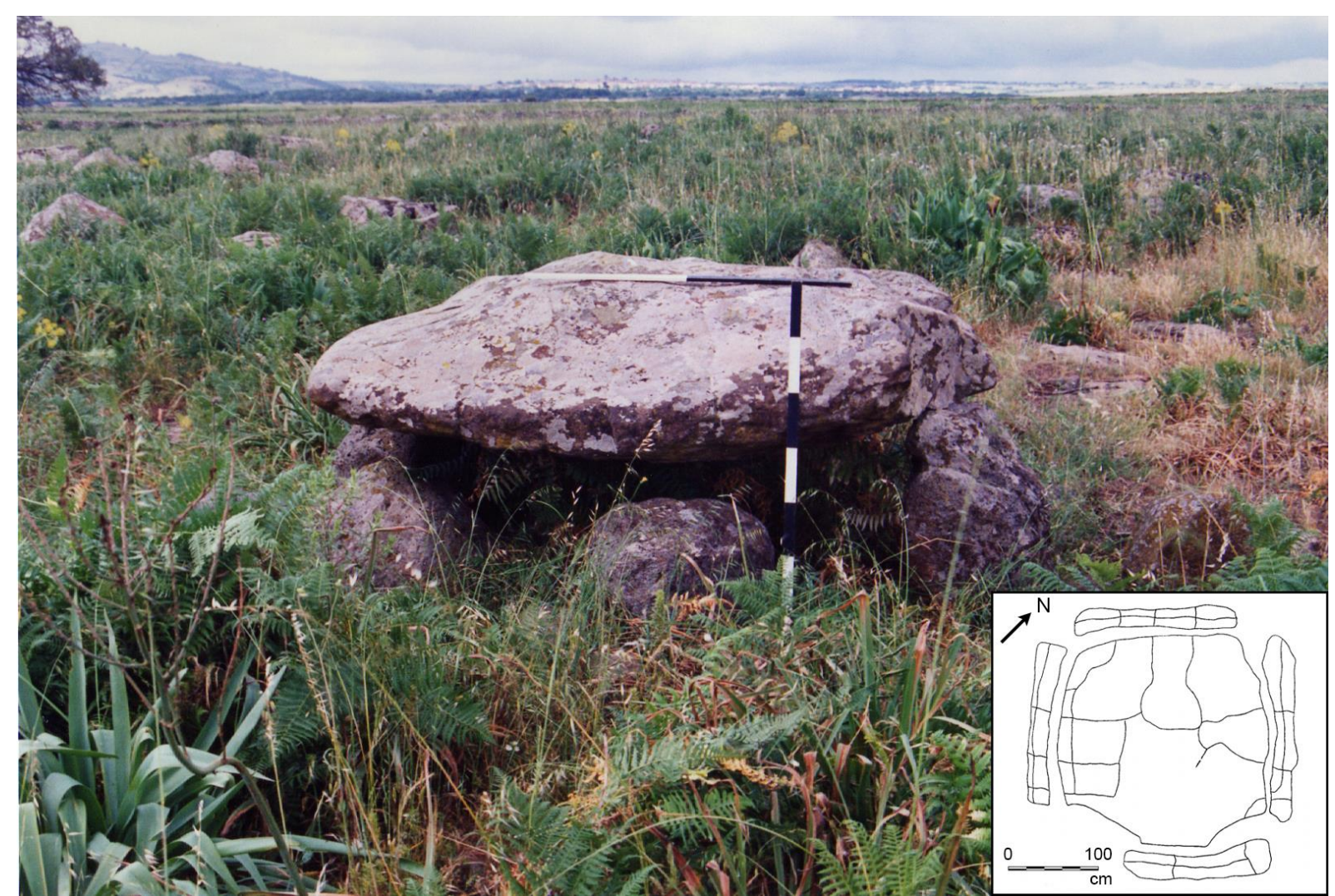

Figure 6. Dolmen Serrese, Sindia (simple type), with petroglyphs on the coverage slab (photo by R. Cicilloni).

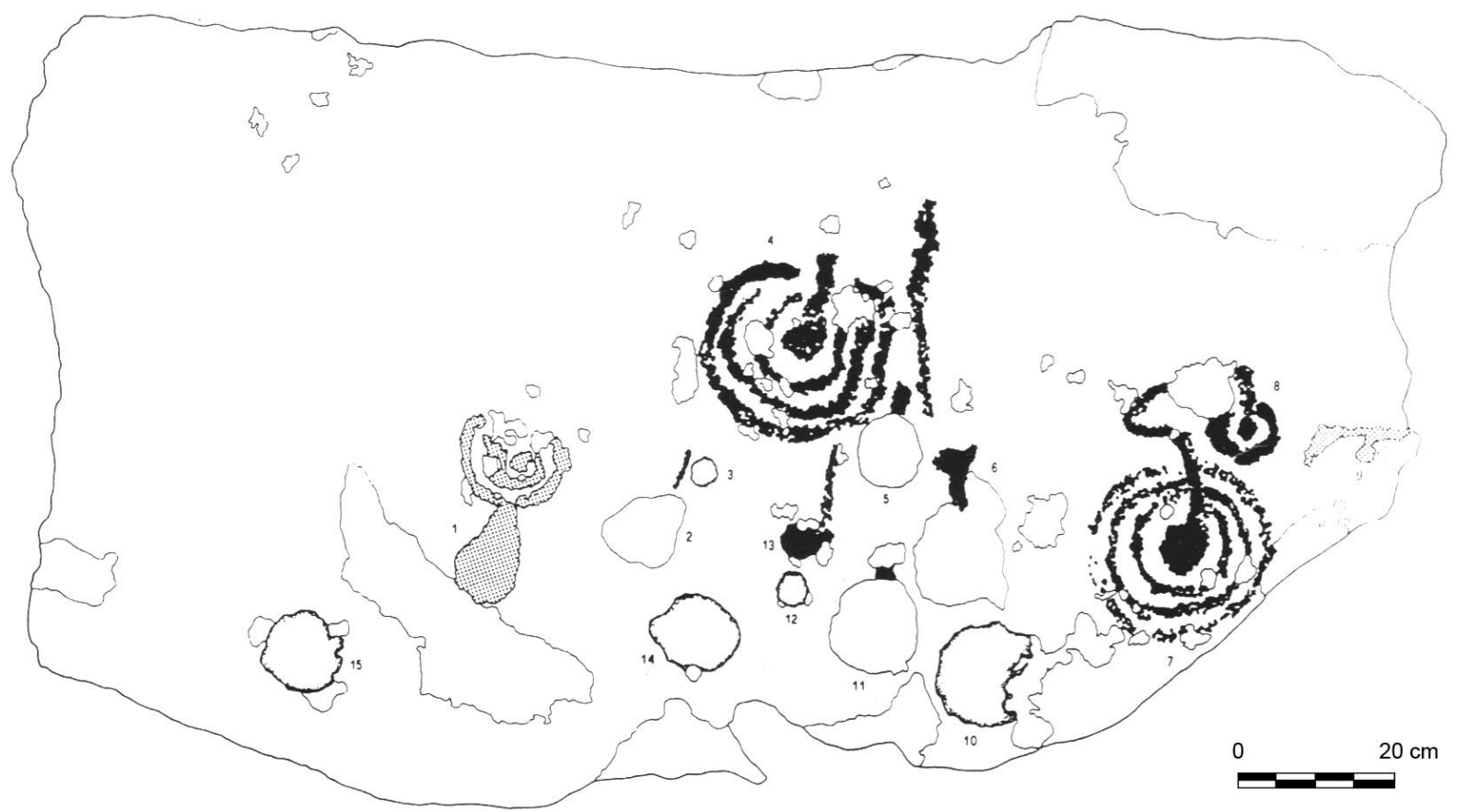

Figure 7. Megalithic monument of Monte Paza-Sedilo (allée couverte type), with petroglyphs on a slab (adapted by Melis 1996). 


\section{Methods}

\subsection{Objectives}

In recent years, the analysis of settlement characteristics of dolmen burials led to an interpretation of this major monumental display - so well diffused across much of Europe being approached as having the role of territorial marker (Chapman 1981; Jarman et al. 1982; Renfrew 1983; Criado Boado 1989; Patton 1992; Barnatt 1998; Thomas 1998; Parker Pearson 1999; Cámara Serrano 2001; Depalmas 2001; Scarre 2007; García Sanjuán 2011). The dolmen assumed a certain symbolic value for those who were to walk the areas in their vicinity and could be compared to the role of contemporary menhirs (Lilliu 1988: 87; Soula 2012: 579) that in many cases are located in proximity of dolmens (Cicilloni 2009: 164-165).

In Sardinia, menhirs associated with dolmens were found at S. Lorenzo, Mesu Serra I, Berre, S. Stefano, Monte Cuccu I-II, Malghesi, Arcone, Montiju Coronas, Oronitta, Monte Sa Rughe I, Monte Mannu, S. Lisei, Sa Pirichedda I, II e III, S. Basilio, Lussurgiu, Sa 'Onca 'e sa 'emina, Minde Puzzu, Sa Corte Noa e San Basilio (Cicilloni 2009: 164-165). The dolmen burials should have a "monumental" connotation as testified by the presence of peristaliths, whose remains are often observed around the central core of the dolmens (Giot 1976: 204205; Cesari 2001: 12; Cicilloni 2009: 21, 150-151). The peristalith is found in the dolmens of Mesu Serra I, Doli Fichima II, Sa Janna de su Laccu, Elcomis, Pubusattile, Su Coveccu, Tespile, Su Urreddu, Nela I, Matta Larentu, Matta Larentu III, Matta Larentu IV, Matta Larentu V, Matta Larentu VI, Tanca Noa A, S. Basilio, Sinne, Motorra, Cucchè-Zia Arvara, Tuide, Sa Perda 'e S'Altare, Tanca Sa Marchesa, Su Edrosu, Terra Tenera, Bidui, Sa Tanca Sar Bogadas, Noazza, Arbu I, Arbu II, Corrizzola, Pradu Lassia, Sculacacca, Sa 'Onca 'e sa 'emina, Badde Ide, Paule Rues, Giuanne Pedraghe, Sa Matta Ide, Serbine A, Arghentu, Monte Lacana, Su Lizu, Sa Cobelcada, Nucrastala, Meddaris, Su Nuradorzu, Scarallotza, Iloi, Lure, Filigorri, Perda Longa, Carazzu, and Sa Corte Noa (Cicilloni 2009: 150-151).

We are in presence of a form of worship linked to the land because there was a contact with it, as also demonstrated by contemporary Domus de Janas (Tanda 2009: 67). Also, the building characteristics of the dolmens reflect undoubtedly the willingness to appear and to visually communicate, that combine well with locational conditions of good visual domain on the surrounding landscape, at the edges of plateaus or in their vicinity, near steep slopes that overlook areas of lower elevation. As regards the nature of these events, some researchers have suggested that they could be related to paths of transhumance (Tanda 2009: 68), within a contrast pattern, traditionally prevalent in the archaeological Sardinian literature, among farming communities, whose funerary aspect manifested itself in the so-called Domus de Janas caves, and pastoral communities, who buried in dolmens (Lilliu 1988: 197).

Without tackling in detail the complex issue of transhumance in Sardinia this aspect can be outlined, at least for Sardinia, in its general features. It is usual, unfortunately, that there is no direct evidence for the final phases of the Late Neolithic and the Copper Age - the chronological range in which are dated the Sardinian dolmens (Cicilloni 2009: 182-183). It is important, however, to clarify the issue.

The territorial object of our analysis is not an area normally affected by historical longrange transhumances known and documented in Sardinia from the Middle Age onwards: those who moved from the areas of Gennargentu, Barbagia, Mandrolisai and Ogliastra towards the regions of Campidano and Sulcis-Iglesiente, Gerrei and Sarrabus, Baronia, Nurra (Ortu 1988: 821), with distances covered between 30-60 and 50-120km, probably by retracing earlier roads. It must be noted that transhumance, in traditionally known continental manifestations, involves moving livestock during hot weather to areas more suitable, in terms of climate, for grazing. The Sardinian phenomenon had though, historically, its opposites in direction and timing. In the island there is a spatial and seasonal different approach by the 
pastor to transhumance, with the aim of spending the cold season, instead of the summer, in places with a warmer climate (Ortu 1988: 822).

In this regard, although it is not possible to treat in detail every local circumstance, literary sources mention the mudas phenomenon, a transhumance of small scale limited to the municipalities or micro-regions of Sardinia (Ortu 1988: 822-823). Transhumance of least distance ("practica de trasterminancia") has been suggested, on the basis of the growing number of farm animals encountered in the archaeological record, for the Copper Age in Seville (Andalucía - Spain) (Murrieta Flores et al. 2011: 214). As Ortu (1988: 824) says, transhumance is "a passage of borders", and it is here that we find the links to some parts of our investigation, with the aspect of boundary marker and at the same time of communication of a message to the outside already advanced by other scholars for several areas of the island (Spanedda \& Cámara 2009: 155), relating to a membership of a group to a territorial entity manifested through megalithic tombs (Afonso Marrero et al. 2010; Spanedda 2010). The claim: "If this step is not legitimate, authorized or agreed, it becomes a 'trespassing' and it is a source of conflict" (Ortu 1988: 823), referred to transhumance, might suggest a vision of the landscape as a palimpsest in which also the people of Sardinian prehistory were closely related with alternate issues of ownership and territorial relationships. Contact areas between groups/people or zones of strategic interest were probably enshrined in monumental form, with single monuments or even as necropoli, witnessed for example at Matta Larentu-Suni (Moravetti 2000: 320-324), Caratzu-Narbolia (Maisola 2012: 53-55) or in an external case to our study area at Su Sordanu-Nughedu San Nicolò (Basoli 1998: 151; Basoli 2001: 107).

It is clear that this parallelism leads us to compare phenomena very distant in time, and it is also clear that the lack of comprehensive stratigraphic data makes more difficult the reconstruction of archaeological context. However, the area of central-western Sardinia - the object of our analysis - offers us a large monumental sample that includes about $40 \%$ of the islanders finds. Having noticed the typical locational choice of the dolmenic burials, we tried to investigate the characters that may have affected movement in these territories. We have tried, thus, to simulate a series of paths that, through the ages, have been able to have a relationship with the dolmens.

At a time when a shepherd designs and reasons about hypothetical shifts functional to relationships that he engages with the territory and its resources, the mobility through the space around it is based and structured according to a set of routes that probably, if they were in direct connection with the activities of subsistence, tended to avoid the most inaccessible areas or difficult journeys, thus making a selection between difficult and easier routes (except when a hard road was required by other reasons, for example for worship). This factor may reflect a stratified knowledge of the area that allowed pastors to trace paths as best functional for the saving of time, manpower, exposure of livestock to the transit, local events - all those situations, in short, of different entities that have happened and still happen in the rural life of the island. To quote F. Cambi,

"It is always the story that produces landscapes, operating on natural environmental frameworks through the actions of man. These, in different ways, and with different complexity, overlap the natural substrate and are part of a historical legacy that is progressively enriched with a process comparable to the unstoppable transformation of an individual's genetic heritage, which continue, even after his death, in subsequent generations" (Cambi 2003: 12).

\subsection{The GIS methodology}

For the analysis, we used the potentialities offered by GIS -- Geographic Information System applications. The software allowed us, first, to store the resulting data from the field 
survey conducted during these years of research and to geo-reference 87 dolmens (about $40 \%$ of the total number known for Sardinia). The dolmens were referenced following a review and update aimed for a more precise clarification of the status of findings that led to adding new monuments compared to the status of research of 2009 (Cicilloni 2009). The production of an updated and accurate map of dolmens of the study area and an accurate geo-referencing were made through field surveys but also thanks to the published research on bibliographic and cartographic heritage, and the webGIS database made available by R.A.S - Regione Autonoma della Sardegna, through its geo-portal.

With GIS it was possible to perform a series of analyses because the georeference data and shapes of the relief were able to be handled in three-dimensional form using a DEM Digital Elevation Model (Wheatley \& Gillings 2002: 95, 96; Conolly \& Lake 2006: 90-111). This is a powerful tool for interpreting physical characteristics of the territorial context. It was also possible to assess, by creating a Cost Surface Model (Wheatley \& Gillings, 2002: 137141; Conolly \& Lake, 2006: 214-215, 221-224, 233), the main trends related to travel routes in relation to the geomorphological characteristics of the environment in which it is configured and the settlement pattern examined (Figure 8).

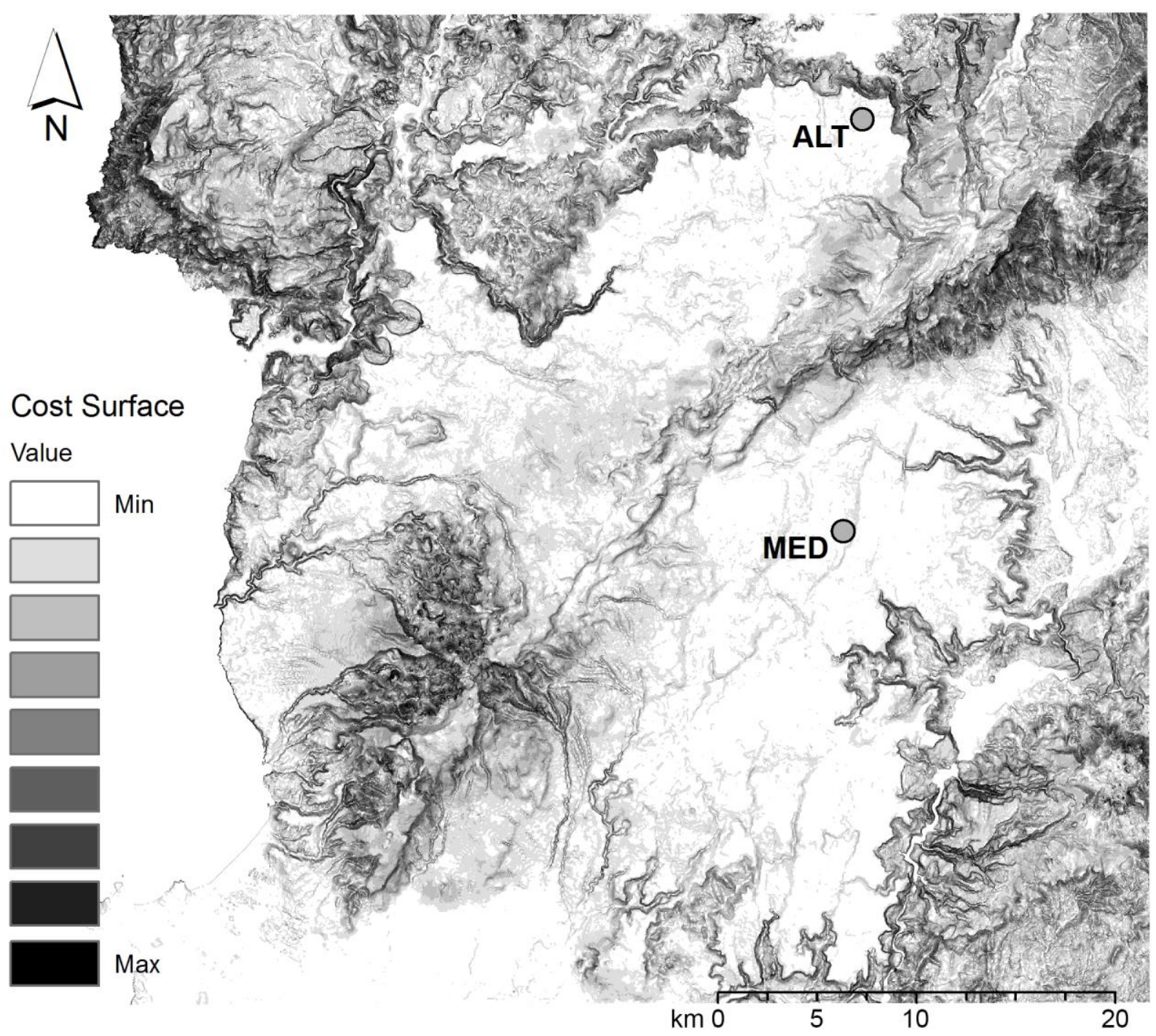

Figure 8.The Cost surface model obtained from a map algebra among the hydrography shapefile and the reclassified slope derived by DTM (Elaboration of M. Cabras). 
Seasonal movement tasks related to pastoralism, therefore, were to take place on paths more or less annually repeated near areas in close relationship, for proximity or intervisibility, with many dolmens. We then calculated the Least Cost Path Analysis (LCPA) (Wheatley \& Gillings, 2002: 142-143; Conolly \& Lake, 2006: 217, 252-255, 262, 294), based on the Cost Surface Model created and calibrated through Reclass and Map Algebra procedures (Wheatley \& Gillings 2002: 84, 92; Conolly \& Lake, 2006: 187-207), taking into account the degree of slope of the terrain and the presence of wet areas and rivers (for some examples of Cost Surface Model calibration, see Pecere 2006: 185-188; Gherdevich 2009: 56-63; Casarotto et al. 2009: 294-300; Camerieri \& Mattioli 2013: 334-337).

Identifying the areas with the lowest cost of traveling on the basis of digital cartography was made possible by a process of interpolation between the layers contours and spot elevations of CTR (Technical Regional Map) with 1.10,000 scale. The simulation of the paths often showed close proximity or coincidence with various types of today's roads. The DTM with 10-metre definition can be downloaded from the geo-portal of the Regione Autonoma della Sardegna. These applications provide a geographic information tool that contains more information than traditional cartography in proposing a 3-D representation of the shapes of the relief and numerical maps on which to base analyses. So we used a tool that allow us to reproduce conditions hard to quantify in a field survey due to the state of preservation of buildings and a lack of perception on the field of ancient landscape conditions covered by the subsequent human actions.

\section{Results}

\subsection{The analysis towards the median point}

By a geo-processing procedure we calculated the median point (Spatial Statistics Tools in ArcGIS) concerning the geographical distribution of dolmens examined. With LCPA we simulated paths that join the dolmens located on the borders of our study area with the geographic median point of the analyzed area. These dolmens are listed in the first column of the Table 1. We operated through this procedure in order to evaluate the spatial relationships of these Least Cost Paths with other non-peripheral dolmens joined on the path towards the median point located on Borore plateau at about 390m above sea level near the Arghentu dolmen. For many of these paths analysis showed that several dolmens, not located in peripheral areas of the global distribution, are located at varying distances to the paths traced by LCPA, often very close.

The Viewshed Analysis (Wheatley \& Gillings, 2002: 179-192; Conolly \& Lake, 2006: 225-232) calculated with a radius of $2.5 \mathrm{~km}$ to a neighborhood of $360^{\circ}$ from one observer placed $2 \mathrm{~m}$ high above ground level in correspondence of each grave has highlighted a complex relationship of the intervisibility of dolmens with several of these Least Cost Paths. This corroborated in our view the relationship of these with important hubs functional to movement within the territory (Figure 9).

\subsection{The relationship between dolmens at different altitudes}

A second analysis was then performed that simulates links within a sample area, chosen by the authors for elevation between 700 and $800 \mathrm{~m}$ above sea level (near the dolmen of Aeddo-Macomer, one of dolmens located at higher altitude), with dolmens located at lower altitudes in order to simulate the activity of transhumance which included shifts towards milder territories during the winter season (Table 2). This analysis also highlighted the results described in Section 3.1. 
Table 1. Distances between Least-Cost Paths from peripheral dolmen towards median point.

\begin{tabular}{|c|c|}
\hline $\begin{array}{l}\text { Dolmen where LCP } \\
\text { begins }\end{array}$ & $\begin{array}{l}\text { Dolmens found along the path and distances } \\
\text { (in metres; accurate to the nearest round figure) }\end{array}$ \\
\hline San Sebastiano & Furrighesu 1250, Muttianu 1070 \\
\hline Cannighedda 'e S'Ena & $\begin{array}{l}\text { S'Angrone 750, Mura 'e Iscovas 660, Abba Muru 1000, Tuvamene } \\
400 \text {, Nucrastala 530, Arghentu } 285\end{array}$ \\
\hline Serrese & Nela 500, Muttianu 1070 \\
\hline Aeddo & Edrosu 790, Muttianu 1070 \\
\hline Pedra in Cuccuru & S'Ispreddosu 500, Tuvamene 1300, Arghentu 1000 \\
\hline Mura 'e Putzu & S'Ispreddosu 185 \\
\hline S'Angrone & $\begin{array}{l}\text { Sa Perda Piccada 315, Mura 'e Putzu 500, Mura 'e Iscovas 880, } \\
\text { Tuvamene 570, Arghentu } 530\end{array}$ \\
\hline Mesu Enas & S'Ispreddosu 185 \\
\hline San Basilio & Mura Pranosa 860, Corrizzola 840, Arbu 160, Serbine A 780 \\
\hline Tanca Noa & Edrosu 780 \\
\hline Nurazzolu & $\begin{array}{l}\text { Arghentu } 270 \text {, Nucrastala 530, Meddaris } 1100 \text {, Tuvamene } 415, \text { Mura } \\
\text { Fratta } 1500 \text {, Mura 'e Iscovas 660, Abba Muru 960, S'Angrone } 1130 .\end{array}$ \\
\hline Abba Muru & $\begin{array}{l}\text { Mura 'e Iscovas 1200, Mura Fratta 1550, Tuvamene 410, Nucrastala } \\
\text { 540, Arghentu } 270\end{array}$ \\
\hline Nurarchei & Arghentu 274, Nucrastala 540, Mura Fratta 1000 \\
\hline Monte Paza & Monte Trigu 350, Iloi 870, Crobecada 62, Nuradorzu 200 \\
\hline Torozzula & Iloi 1400, Crobecada 62, Nuradorzu 196 \\
\hline Filigorri & Nuradorzu 350, Paule Rues 1060, Baratta 450, Lure 0 \\
\hline Monte Lacana & $\begin{array}{l}\text { Su Lizzu 470, Su Livrandu 20, Giuanne Pedraghe 410, Muttianu 40, Sa } \\
\text { Cobelcada } 1000\end{array}$ \\
\hline Mazzarighe A & Lughe 110, Sa Fronte Uda 390, Mazzarighe B 210 \\
\hline Baccarzos & Brancatzu 500, Badde Ide 570, Baratta 530, Paule Rues 310 \\
\hline Noazza & Pradu Lassia 115, Sarbogadas 360, Serbine A 74, Serbine B 170 \\
\hline Carrarzu Iddia & $\begin{array}{l}\text { Sa Matta 'e Sa Ide 43, Serbine B 660, Serbine A 770, Perda 'e S'Altare } \\
\text { 190, Bidui 50, Noazza } 900\end{array}$ \\
\hline Tuide & Muttianu 1060 \\
\hline Nole & $\begin{array}{l}\text { Monte Paza 600, Monte Trigu 750, Crobecada 65, Sa Tanca 'e } \\
\text { S'Ozzastru 830, Nuradorzu 200, Meddaris 950, Arghentu 920, Aeddo } \\
\text { 820, Edrosu } 800\end{array}$ \\
\hline
\end{tabular}

However, in totality, dolmens show an elevation relationship that is not much heterogeneous. It is correct to keep in mind that many monuments are considerably distant from the paths traced by LCPA although sometimes they retain a relationship of intervisibility.

The anomaly, if there is one, may be in the parameters (certainly implementable) that we entered into the software in order to calibrate the Cost Surface Model (Figure 9). Also, we may be in the presence of groups of dolmens that do not have strategic characters but probably other tasks within the territorial organization, perhaps with "symbolic" meanings. 

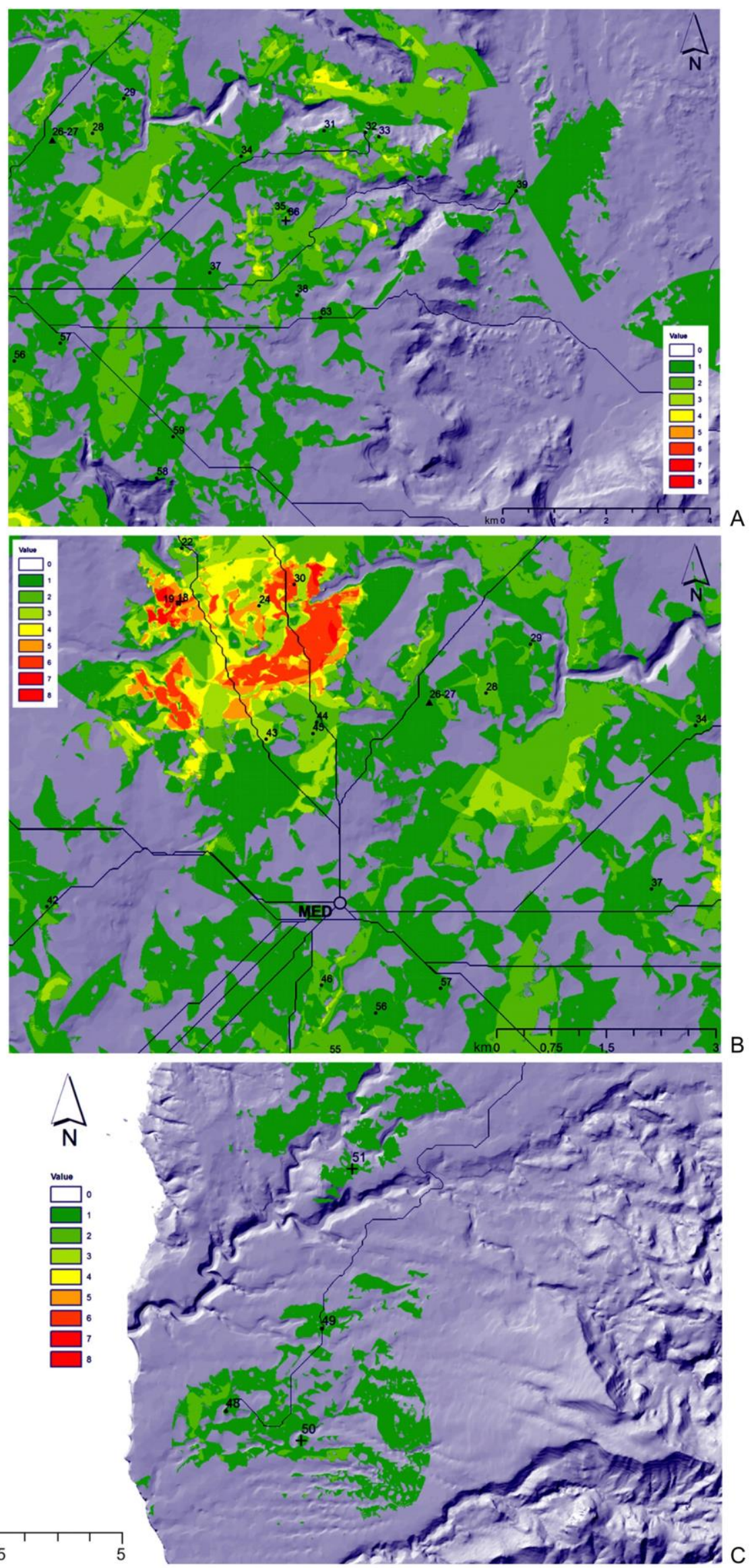

Figure 9. Spatial relationships between Cost paths and dolmens: A, B - The area of Dualchi, Aidomaggiore, Birori, Macomer, Borore, Noragugume; C - The coastal area near Cuglieri (Elaboration of M. Cabras). 
Table 2. Least-Cost Path Analysis from the sample area towards dolmen located at lower altitudes. (Distances in metres; accurate to the nearest round figure.)

\begin{tabular}{|c|c|}
\hline Arrival dolmen & Dolmens found along the path and distances \\
\hline Caratzu & $\begin{array}{l}\text { Cannighedda 'e S'Ena 1600, Mesu Enas 1080, Pedra in Cuccuru 620, } \\
\text { Giuanne Pedraghe 480, Edrosu } 800\end{array}$ \\
\hline Cannighedda 'e S'Ena & $\begin{array}{l}\text { Mesu Enas 540, Mura 'e Putzu 750, Sa Perda Piccada 1000, } \\
\text { S'Angrone 670, S'Ispreddosu 770, Giuanne Pedraghe 440, Edrosu } \\
800\end{array}$ \\
\hline Nurazzolu & $\begin{array}{l}\text { Cannighedda 'e S'Ena 1040, S'Angrone 650, Mesu Enas 540, Mura 'e } \\
\text { Putzu 750, Sa Perda Piccada 1000, S'Ispreddosu 770, Giuanne } \\
\text { Pedraghe 440, Edrosu } 800\end{array}$ \\
\hline Mura 'e Iscovas & $\begin{array}{l}\text { Sa Perda Piccada 650, Mura 'e Putzu 940, S'Ispreddosu 25, Giuanne } \\
\text { Pedraghe 440, Edrosu } 800\end{array}$ \\
\hline Torozzula & $\begin{array}{l}\text { Iloi 1400, Tanca 'e S'Ozzastru 850, Crobecada 60, Nuradorzu 200, } \\
\text { Edrosu } 800\end{array}$ \\
\hline San Basilio & $\begin{array}{l}\text { Pradu Lassia 160, Sarbogadas 230, Perda 'e S'Altare 1050, Edrosu } \\
800\end{array}$ \\
\hline Mazzarighe B & $\begin{array}{l}\text { Mazzarighe A } 240 \text {, Sa Fronte Uda 390, Lughe 123, Corrizzola 610, } \\
\text { Arbu 15, Edrosu } 800\end{array}$ \\
\hline Monte Trigu & Iloi 870, Crobecada 60, Nuradorzu 200, Edrosu 800 \\
\hline Succhiau & Mura Fratta 70, Tuvamene 250, Muttianu 230, Edrosu 800 \\
\hline Carrarzu Iddia & Tuide 430 \\
\hline Sa Perda 'e S'Altare & Bidui 700, Edrosu 800 \\
\hline Noazza & $\begin{array}{l}\text { Bidui 820, Pradu Lassia 625, Sarbogadas 470, Perda 'e S'Altare 370, } \\
\text { Edrosu } 800\end{array}$ \\
\hline Baccarzos & $\begin{array}{l}\text { Badde Ide 470, Brancatzu 670, Sa Fronte Uda 900, Mazzarighe B 970, } \\
\text { Lughe 570, Corrizzola 610, Arbu 10, Edrosu } 800\end{array}$ \\
\hline Filigorri & $\begin{array}{l}\text { Lure 0, Baratta 450, Paule Rues 1050, Nuradorzu 650, Meddaris 950, } \\
\text { Edrosu } 800\end{array}$ \\
\hline Monte Lacana & $\begin{array}{l}\text { Su Livrandu 20, Serrese 1300, Furrighesu 520, Terra Tenera 2000, } \\
\text { Aeddo 900, Nela } 1550\end{array}$ \\
\hline Nurarchei & $\begin{array}{l}\text { Abba Muru 1340, Succhiau 1850, Mura Fratta 1500,Tuvamene } 820 \text {, } \\
\text { Muttianu 230, Edrosu } 800\end{array}$ \\
\hline
\end{tabular}

\section{Discussion and conclusions}

The study of the location of Sardinian dolmens was carried out taking into account the geomorphology of the environment. The analysis, through precise geo-referencing of each monument and with the application of GIS tools, seems to confirm what has already been highlighted in previous studies with the macroscopic analysis of the phenomenon.

But there are problems: the analysis was carried out taking into account the actual landscape, which, however, in a land almost untouched like Sardinia, with very little human intervention, should not deviate too much from that of the Neolithic and Copper Age. Clearly, landscape changes, not easily appraisable, have occurred, for example in the vegetation coverage of the area and probably in the hydrography of the area. These features of the territory have certainly conditioned the locational choices of human groups. It is also necessary to excavate dolmen burials to find new data, pertinent to the stratigraphic context both palaeobotanical and palaeoenvironmental. 
The researches have highlighted some features that recur with a certain constancy. First, many of the dolmens considered are very close to nature trails, sometimes coinciding with canyons or valleys (Figure 9). Moreover, these monuments, as compared with natural ways and, in general, to the surrounding area, are highly visible, although the number of these dolmens is not so great in this area. The data resulting from the analysis however, have not given precise and unequivocal answers, as might be expected, about any connection between dolmens and routes of transhumance. In any case, the study highlighted the strategic nature of the areas interested by the dolmen phenomenon.

Next, it is confirmed that the distribution of the dolmens is scattered over the whole area: in fact, these monuments are rarely grouped in necropoli, but are usually isolated.

To these elements can be added the data constituted by the coexistence, in the same territories such as the plateau of Campeda, of dolmens and the more numerous rock-cut tombs (denominated in local language "Domus de Janas" - fairy houses). The latter are datable to the Late Neolithic and Copper Age, in use at the same time as the dolmens.

All of this leads us to believe that the Sardinian dolmens, as opposed to artificial caves called "domus de janas" (spaces essentially funerary and ritual), should have not just a funerary function, but also some "political" purpose. In fact, these monuments could be interpreted as "signs of territorial demarcation of segmentary societies", agreeing with the hypothesis proposed by Renfrew (1976), with functions of control and organization of the territory.

During the Late Neolithic (characterized by the Ozieri culture), and the later Copper Age, small groups of farmers and shepherds, who lived locally and were not part of a centralized society of chiefs, in some areas may have felt the need of a first territorial organization: the possession of the territory could be well testified by the presence of megalithic tombs, perhaps pertinent to burials of ancestors, leaders or heroes of the various communities. The scattered distribution of dolmens in this territory and the remoteness of some sites by real and potential paths, highlighted by LCPA, could suggest a kind of "hierarchical structure" of the landscape as regards the funeral area, perhaps following a process of progressive 'gemmation' from primary burial phenomena.

\section{Acknowledgements}

We are grateful to Prof. Terence Meaden for his support and helpful comments on this paper.

\section{References}

Afonso Marrero, J. A., Cámara Serrano, J. A. \& Spanedda, L. 2010, Links between megalithism and hypogeism in western mediterranean Europe: An approach. In: Links between Megalithism and Hypogeism in Western Mediterranean Europe (Cámara Serrano, J. A., Afonso Marrero, J. A. \& Spanedda, L., Eds.), BAR International Series Vol. 2151, Archaeopress, Oxford: p. 3-11.

Angius, V., Antona, A., Puggioni, S., Spanedda, L. 2010, Demografia e popolamento nella Sardegna dell'età del bronzo: Un confronto tra la regione della Gallura e l'area di Dorgali attraverso analisi GIS. Arqueología Espacial, 28: 189-207. (in Spanish) ("Demography and peopling of Sardinia in the Bronze Age: A comparison between the Gallura region and the area of Dorgali through GIS analysis") 
Angius, V., Antona, A., Cadeddu, F. \& Puggioni, S. 2012, Territorio e popolamento nella Gallura nuragica. Un'ipotesi metodologica. In: La Preistoria e la Protostoria della Sardegna. Atti della XLIV Riunione Scientifica dell'I.I.P.P., 23-28 novembre 2009 Cagliari-Barumini-Sassari, 3, (Lugliè, C., Ed.), Istituto Italiano di Preistoria e Protostoria, Firenze: p. 1215-1221. (in Italian) ("Territory and population in the nuragic Gallura. A methodological hypothesis")

Atzeni, E. 1968, Il dolmen "Sa Coveccada" di Mores e la tomba di giganti "Sa domu 'e s'orku” di Quartucciu. Studi Sardi, 20(1966-1967): 129-151. (in Italian) (“The dolmen 'Sa Coveccada'-Mores and the Giant's tomb 'Sa domu 'e s'orku'-Quartucciu)

Atzeni, E. 1982, Laconi (Prov. di Nuoro). Corte Noa. Rivista di Scienze Preistoriche, 37: 336-337. (in Italian) ("Laconi-Province of Nuoro. Corte Noa")

Atzeni, E. 1988, Tombe megalitiche di Laconi (Nuoro). Rassegna di Archeologia, 7: 526-527. (in Italian) ("Megalithic tombs of Laconi - Nuoro")

Atzeni, E. 1998, Le Statue-Menhir di Piscina 'e Sali, Laconi-Sardegna. Archeologie en Languedoc, 22: 61-72. (in Italian) ("The Statue-Menhirs of Piscina 'e Sali, LaconiSardinia")

Barnatt, J. 1998, Monuments in the landscape: Thoughts from the Peak. In: Prehistoric ritual and religion (Gibson, A., Simpson, D., Eds.), Sutton Publishing, Phoenix: p. 92-105.

Basoli, P. 1998, Aspetti del megalitismo nel territorio di M. Acuto (Sassari). Considerazioni preliminary. In: Sardinian and Aegean Chronology (Balmuth, M. S. \& Tykot, R. H., Eds.), Oxbow, Oxford: p. 141-158. (in Italian) ("Aspects of megalithism in the territory of M. Acuto-Sassari”)

Basoli, P. 2001, Aspetti del megalitismo nel territorio del Monte Acuto: La religione megalitica. In: Aspetti del megalitismo preistorico (Serreli, G. \& Vacca, D., Eds.), Grafica del Parteolla, Dolianova: p. 107-110. (in Italian) ("Aspects of megalithism in the territory of M. Acuto: The megalithic religion")

Cámara Serrano, J. A. 2001, El ritual funerario en la Prehistoria Reciente en el Sur de la penìnsula Ibérica. BAR International Series Vol. 913, Archaeopress, Oxford, 346 p. (in Spanish) ("The funeral ritual in the Late Prehistory in the south of the Iberian Peninsula")

Cambi, F. 2003, Archeologia dei paesaggi antichi: Fonti e diagnostica. Carocci, Roma, 125 p. (in Italian) ("Archaeology of the ancient landscapes: Sources and diagnostic")

Camerieri, P. \& Mattioli, T., 2013, Obscura itinera: A GIS-based approach to understand the pre-Roman and Roman transhumance pathways in Umbria and Sabina regions (Central Italy). In: Archaeology in the Digital Era. Papers from the 40th Annual Conference of Computer Applications and Quantitative Methods in Archaeology (CAA), 26-29 March 2012 Southampton (Earl, G., Sly, T., Chrysanthi, A., Murrieta-Flores, P., Papadopoulos, C., Romanowska, I. \& Wheatley, D., Eds.), Amsterdam University Press, Amsterdam: p. 332-339.

Casarotto, A., De Guio, A. \& Ferrarese, F. 2009, Action GIS: Un modello predittivo del movimento antropico in un paesaggio antico. Il caso di studio archeologico della Val D'Alpone (VR). Archeologia e Calcolatori, 20: 291-307. (in Italian) (“Action GIS: A predictive model of the anthropic movement in an ancient landscape. The case of archaeological study of Val D'Alpone, VR"),

URL: http://soi.cnr.it/archcalc/indice/PDF20/22_Casarotto.pdf 
Cesari, J. 2001, Le dolmen de Figa alla Sarra (Olmeto, Corse-du-Sud) dans son contexte archéologique. In: Architettura arte e artigianato nel Mediterraneo dalla Preistoria all'alto Medioevo. Atti della Tavola Rotonda Internazionale in memoria di Giovanni Tore, 17-19 dicembre 1999 Cagliari, (Associazione culturale Nissardi, Ed.), S'Alvure, Oristano: p. 9-46. (in French) ("The dolmen de Figa alla Sarra, Olmeto-Southern Corse, in its territorial context")

Chapman, R. 1981, The emergence of formal disposal areas and the "problem" of megalithic tombs in prehistoric europe. In: The Archaeology of Death (Chapman, R., Kinnes, I. \& Randsborg, K., Eds.), Cambridge University Press, Cambridge: p. 71-81.

Chevalier, Y. 1984, L'architecture des dolmens entre Languedoc et Centre-Ouest de la France. Dr. Rudolf Habelt, Bonn, 287 p. (in French) ("The architecture of the dolmens in Languedoc and in the central-western France")

Cicilloni, R. 1997, Note su alcuni monumenti dolmenici in provincia di Oristano. Quaderni della Soprintendenza Archeologica di Cagliari e Oristano, 14: 45-61. (in Italian) ("Notes on some dolmenic monuments of the Oristano province")

Cicilloni R. 2009, I Dolmen della Sardegna. Prima Tipografia Mogorese, Mogoro, 318 p. (in Italian) ("The dolmens of Sardinia")

Cicilloni, R. \& Cabras, M. 2014, Aspetti insediativi nel versante orientale del Monte Arci (Oristano - Sardegna) tra il Bronzo Medio e la I età del Ferro. Quaderni della Soprintendenza Archeologica di Cagliari e Oristano, 25: 81-107. (in Italian) ("Settlement aspects in the eastern side of Monte Arci, Oristano-Sardinia, from Middle Bronze Age to Iron Age")

URL: http://www.quaderniarcheocaor.beniculturali.it/index.php/quaderni/article/view/2 10

Conolly, J. \& Lake, M. 2006, Geographical Information Systems in archaeology. Cambridge University Press, Cambridge, 358 p. doi:10.1017/cbo9780511807459

Criado Boado, F. 1989, Megalitos, espacio, pensamiento. Trabajos de Prehistoria, 46: 75-98. (in Spanish) ("Megaliths, space, thinking") doi:10.3989/tp.1989.v46.i0.588

Davies, O. 1939, The horned cairns of Sardinia. Ulster Journal of Archaeology, 3: 158-169. Stable URL: http://www.jstor.org/stable/20627285

Depalmas, A. 2001, I monumenti megalitici nello spazio delle comunità delle età dei metalli. In: Aspetti del megalitismo preistorico (Serreli, G. \& Vacca, D., Eds.), Grafica del Parteolla, Dolianova: p. 99-106. (in Italian) ("The megalithic monuments in the space of the communities in the age of metals in Sardinia")

Esteva Cruañas, L. 1970, Sepulcros megaliticos de Las Gabarras (Gerona), III. Instituto Español de Prehistoria del Consejo Superior de Investigaciones Científicas, Gerona, 21 p. (in Spanish) ("Megalithic graves of Las Gabarras-Girona. III")

Fadda, M.A. 1997, Una nuova statua menhir. Archeologia Viva, 65 (Settembre-Ottobre 1997): 13. (in Italian) ("A new statue-menhir") 
Fenu P., Pizziolo G. \& Sanna, R. 2012, Adozioni di metodologie analitiche in ambiente GIS per la ricostruzione del paesaggio pre e protostorico in Anglona. In: La Preistoria e la Protostoria della Sardegna. Atti della XLIV Riunione Scientifica dell'I.I.P.P., 23-28 novembre 2009 Cagliari-Barumini-Sassari, 3, (Lugliè, C., Ed.), Istituto Italiano di Preistoria e Protostoria, Firenze: p. 1189-1193. (in Italian) (“Adoptions of GIS analytical methods for the reconstruction of the prehistoric and protohistoric landscape in the region of Anglona")

García Sanjuán, L. 2011, Transformations, invocations, echoes, resistance: The assimilation of the past in southern Iberian monumental landscapes (5th to 1st millennia BC). In: Comparative Archaeologies: The US Southwest and the Iberian Peninsula (Lillios, K., Ed.), Oxbow Books, Oxford: p. 81-102.

Gherdevich D. 2009, L'analisi spaziale come strumento per la ricostruzione della viabilità antica del Friuli Venezia Giulia. Phd thesis at the Mathematic Sciences Department, University of Trieste, Trieste, 142 p. (in Italian) ("The spatial analysis as a tool for the reconstruction of the ancient roads in Friuli Venezia Giulia").

URL: https://www.openstarts.units.it/dspace/bitstream/10077/3139/1/Tesi_dottorato.pdf

Giot, P. R. 1976, Le mégalithisme. Dolmens et Menhirs, le phénomène mégalithique en France. In: La Préhistoire française. II. Les civilisations néolithiques et prothostoriques de la France (Guilaine, J., Ed.), Ėditions du Centre National de la Recherche Scientifique, Paris: p. 202-210. (in French) ("The megalithism. Dolmen and menhirs, the megalithic phenomenon in France")

Hoskin, M. 2001, Tombs, Temples and Their Orientations. A New Perspective on Mediterranean Prehistory. Oxbow Books, Oxford, 264 p.

Jarman, M.R., Bayley, G. N. \& Jarman, H.R. 1982, Early European Agricolture. Its Foundation and Development. Cambridge University Press, Cambridge, 296 p.

Lilliu, G. 1968, Il dolmen di Motorra (Dorgali-Nuoro). Studi Sardi, 20 (1966-1967): 74-128. (in Italian) ("The dolmen Motorra, Dorgali-Nuoro")

Lilliu, G. 1988, La civiltà dei Sardi dal paleolitico all'età dei nuraghi. Nuova Eri, Torino, 679 p. (in Italian) ("The civilization of the Sardinians from Paleolithic to nuragic age")

Loi, C. 2012, Testimonianze archeologiche nel territorio del Comune di Neoneli. Iskra, Ghilarza, 127 p. (in Italian) ("Archaeological evidences in the Municipality of Neoneli")

Mackenzie, D. 1910, The dolmens, Tombs of the Giants and Nuraghi of Sardinia. Papers of the British School at Rome, 5: 87-137. doi:10.1017/S0068246200005237

Mackenzie, D. 1913, Dolmens and nuraghi of Sardinia. Papers of the British School at Rome, 6: 127-170. doi:10.1017/S0068246200001240

Manca, G. \& Zirottu, G. 1999, Pietre magiche a Mamoiada. Associazione folk Mamuthones e issohadores "Peppino Beccoi", Nuoro, 357 p. (in Italian) ("Magic stones at Mamoiada")

McNally, K. 2006, Ireland's Ancient Stones. A megalithic Heritage. Appletree Press, Belfast, $144 \mathrm{p}$.

Maisola, G. 2012, Ricerche di archeologia dei paesaggi nell'alto Oristanese. Phd thesis at the History Department, University of Sassari, Sassari, 396 p. (in Italian) ("Landscapes archaeological researches in the northern region of Oristano province").

URL: http://eprints.uniss.it/6814/ 
Melis, M.G. 1996, Scheda 89 (216) - Monte Paza - Tomba megalitica. In: Sedilo. I monumenti. Tomo I. I monumenti situati nell'area del progetto (Tanda, G., Ed.), Soter, Villanova Monteleone: p. 217-218. (in Italian) ("Record 89 (216) - Monte Paza Megalithic Tomb")

De Montis A. \& Caschili, S. 2012, Nuraghes and landscape planning: Coupling viewshed with complex network analysis. Landscape and Urban Planning, 105: 315-324. doi:10.1016/j.landurbplan.2012.01.005

Moravetti, A. 1998a, On the dolmens of pre-nuragic Sardinia. In: Papers from EAA Third Annual Meeting at Ravenna, vol. III: Sardinia (Moravetti, A., Pearce, M. \& Tosi, M., Eds.), BAR International Series Vol. 719, Archaeopress, Oxford: p. 25-45.

Moravetti, A. 1998b, Ricerche archeologiche nel Marghine-Planargia. I. C. Delfino, Sassari, 727 p. (in Italian) (“Archaeological researches in the Marghine-Planargia. I.")

Moravetti, A. 2000, Ricerche archeologiche nel Marghine-Planargia. II. C. Delfino, Sassari, 591 p. (in Italian) ("Archaeological researches in the Marghine-Planargia. II.")

Mori, A. 1975, Sardegna. Le regioni d'Italia, 18. Unione tipografico-editrice torinese, Torino, 695 p. (in Italian) ("Sardinia")

Murrieta Flores, P. A., Wheatley, D. W. \& García Sanjuán, L. 2011, Movilidad y vías de paso en los paisajes prehistóricos: Megalitos y vías pecuarias en Almadén de la Plata. In:

Tecnologías de información geográfica y análisis arqueológico del territorio, Actas del V Simposio Internacional de Arqueología de Mérida, (Mayoral Herrera, V. \& Pérez, S.C., Eds.), Anejos de Archivo Español de Arqueología Vol. 59, Consejo Superior de Investigaciones Científicas, Merida: p. 411-423. (in Spanish) ("Mobility and pathways in prehistoric landscapes: Megaliths and cattle trails in Almadén de la Plata")

Ortu, G.G. 1988, La transumanza nella storia della Sardegna. Mélanges de l'Ecole française de Rome, 100 (2): 821-838. (in Italian) ("Transhumance in the history of Sardinia") doi:10.3406/mefr.1988.2990

Parker Pearson, M. 1999, The Archaeology of Death and Burial. Sutton Publishing Ltd., Stroud, $250 \mathrm{p}$.

Paschina, I. 2000, Monumenti archeologici del Marghine. Studio sul foglio IGM 206 I NO Macomer. Stamperia Artistica, Sassari, 515 p. (in Italian) ("Archaeological monuments in the Marghine. Study on IGM 206 I NO Macomer")

Patton, M. 1992, Megalithic transport and territorial markers: Evidence from the Channel Islands. Antiquity, 66: 392-395. doi:10.1017/s0003598x00081503

Pecere, B. 2006, Viewshed e Cost Surface Analyses per uno studio dei sistemi insediativi antichi: Il caso della Daunia tra X e VI secolo a.C.. Archeologia e Calcolatori, 17: 177213. (in Italian) ("Viewshed and Cost Surface Analyses for a study of the ancient settlement systems: The case of the Daunia during the $10^{\text {th }}-6^{\text {th }}$ centuries B.C."). URL: http://soi.cnr.it/archcalc/indice/PDF17/11_Pecere.pdf

Pes, P. 2009, Archeologia tra Planargia e Montiferru. Edizioni di Antonino Valveri, Cagliari, 330 p. (in Italian) (“Archaeology in Planargia and Montiferru”) 
Puggioni, S. 2009, Patrones de asentamiento de la Edad del Bronce en el territorio costero e interior de la Cerdeña nororiental. Phd thesis at the Prehistory and Archaeology Department, University of Granada, Granada, 512 p. (in Spanish) ("Settlement patterns in the coastal and internal territory of North-East Sardinia during the Bronze Age"). URL: http://digibug.ugr.es/bitstream/10481/2401/1/18157750.pdf

Renfrew, C. 1976, Megaliths, territories and population. In: Acculturation and Continuity in Atlantic Europe (De Laet, S. J., Ed.), De Tempel, Brugge: p. 198-220.

Renfrew, C. 1983, Introduction: The Megalithic Builders of Western Europe. In: The Megalithic Monuments of Western Europe (Renfrew, C., Ed.), Thames \& Hudson, London: p. 8-17.

Sanna, V. 2012, Analisi Spaziale in ambiente GIS: Un caso di studio. In: La Preistoria e la Protostoria della Sardegna. Atti della XLIV Riunione Scientifica dell'I.I.P.P., 23-28 novembre 2009 Cagliari-Barumini-Sassari, 3 (Lugliè, C., Ed.), Istituto Italiano di Preistoria e Protostoria, Firenze: p. 1195-1200. (in Italian) ("GIS-based spatial analysis: A case of study")

Santoni, V. 1973, Il dolmen di Sculacacca (Oniferi-Nuoro). Studi Sardi, 22(1971-1972): 3-37. (in Italian) ("The dolmen of Sculacacca, Oniferi-Nuoro")

Scarre, C. 2007, Megalithic Monuments of Britain and Ireland. Thames \& Hudson, London, $118 \mathrm{p}$.

Shee Twohig, E. 1981, The Megalithic Art of Western Europe. Clarendon Press, Oxford, $259 \mathrm{p}$.

Soula, F. 2012, Studio sistemico delle pietre fitte del territorio di Mamoiada (Nuoro, Sardegna), In: La Preistoria e la Protostoria della Sardegna. Atti della XLIV Riunione Scientifica dell'I.I.P.P., 23-28 novembre 2009 Cagliari-Barumini-Sassari, 2, (Lugliè, C., Ed.), Istituto Italiano di Preistoria e Protostoria, Firenze: p. 577-583. (in Italian) ("Systemic study of the standing stones of Mamoiada territory -Nuoro, Sardinia")

Spanedda, L. 2010, Megaliths and rock-cut tombs in northeastern Sardinia: From spatial consecration to the demarcation of territorial boundaries. In: Links between Megalithism and Hypogeism in Western Mediterranean Europe (Cámara Serrano, J. A., Afonso Marrero, J. A. \& Spanedda, L., Eds.), BAR International Series Vol. 2151, Archaeopress, Oxford: p. 53-75.

Spanedda, L. \& Cámara Serrano, J. A. 2009, Control territorial a partir de monumentos rituales en el Golfo de Orosei (Cerdeña, Italia) durante la Prehistoria Reciente. Sardinia, Corsica et Baleares Antiqvae. International Journal of Archaeology, 7: 153-170. (in Spanish) ("Territorial control, starting from the ritual monuments, during the late Prehistory in the Orosei Gulf- Sardinia, Italy"). doi:10.1400/143013

Tanda, G., (Ed.), 1996, Sedilo. I monumenti. Tomo I. I monumenti situati nell'area del progetto. Soter, Villanova Monteleone, 268 p. (in Italian) ("Sedilo. The monuments. Tome I. The monuments located in the project area")

Tanda, G., (Ed.), 1997, Sedilo. I monumenti. Tomo II. I monumenti del territorio del Comune. Soter, Villanova Monteleone, 269 p. (in Italian) ("Sedilo. The monuments. Tome II. The monuments in the municipal territory")

Tanda, G., (Ed.), 1998, Sedilo. I monumenti. Tomo III. I monumenti nel contesto territoriale comunale. Soter, Villanova Monteleone, 234 p. (in Italian) ("Sedilo. The monuments. Tome III. The monuments in the context of the municipal territory") 
Tanda, G. 2009, Il Neolitico recente. In: La Preistoria e la Protostoria della Sardegna. Atti della XLIV Riunione Scientifica dell'I.I.P.P., 23-28 novembre 2009 Cagliari-BaruminiSassari, Vol. 1, (Lugliè, C. \& Cicilloni, R., Eds.), Istituto Italiano di Preistoria e Protostoria, Firenze: p. 59-71. (in Italian) ("The Late Neolithic")

Taramelli, A. 1906, Dolmen "Sa Perda e s'altare" nel comune di Birori in provincia di Cagliari. Bullettino di Paletnologia Italiana, 32: 268-271. (in Italian) ("Dolmen "Sa Perda e s'altare" in the municipality of Birori, province of Cagliari")

Taramelli, A. 1916, ABBASANTA- Ricerche nel nuraghe Losa. Notizie degli Scavi di Antichità, 41(7): 235-259. (in Italian) ("ABBASANTA- Researches in the nuraghe Losa")

Taramelli, A. 1919, BUDDUSÒ-Monumenti preistorici vari, fontana coperta di Sos Muros, dolmen di Sos Monimentos e nuraghe Iselle. Notizie degli Scavi di Antichità, 44 (4-6): 127-132. (in Italian) ("BUDDUSÒ - Various prehistoric monuments, underground fountain of Sos Muros, dolmen of Sos Monimentos and nuraghe Iselle")

Thomas, J. 1998, Towards a Regional Geography of the Neolithic. In: Understanding the Neolithic of North-Western Europe (Edmonds, M. \& Richards, C., Eds.), Cruithne Press, Glasgow: p. 37-60.

Usai, A. 1999, Osservazioni sul popolamento prenuragico e nuragico nel territorio di Norbello (OR). Quaderni della Soprintendenza Archeologica di Cagliari e Oristano, 16: 51-79. (in Italian) ("Observations on the prenuragic and nuragic population in the territory of Norbello-Oristano")

Usai, A. 2005, Testimonianze Prenuragiche e Nuragiche nel territorio di Narbolia. In: Nurabolia-Narbolia. Una Villa di frontiera del Giudicato d'Arborea (Zucca, R., Ed.). Grafiche editoriali Solinas, Nuoro: p. 21-57. (in Italian) ("Prenuragic and nuragic evidences in the territory of Narbolia")

Vanzetti, A., Castangia, G., Depalmas, A., Ialongo, N., Leonelli, V., Perra, M. \& Usai, A. 2013, Complessi fortificati della Sardegna e delle isole del Mediterraneo occidentale nella protostoria. In: Mura di legno, mura di terra, mura di pietra: Fortificazioni nel Mediterraneo antico, Atti del Convegno Internazionale, 7-9 Maggio 2012 Roma, (Bartoloni, G. \& Michetti, L. M., Eds.), Scienze dell'Antichità, 19, 2/3, Quasar, Roma: p. 83-123. (in Italian) ("Fortified sites of Sardinia and in the islands of the Western Mediterranean during the protohistory")

Wheatley, D. \& Gillings, M. 2002, Spatial technology and archaeology. The archaeological applications of GIS. Taylor and Francis, New York, 269 p. 